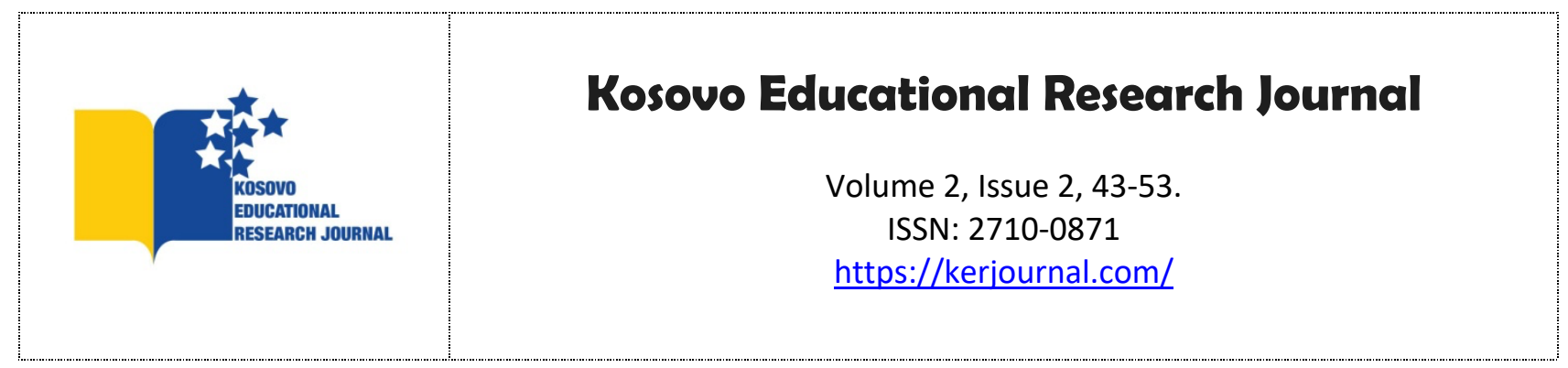

\title{
Okul Öncesi Öğretmen Adaylarının Çocuk Sevgisi ve Mesleki Kaygılarının İncelenmesi
}

\author{
Esen SPAHI KOVAÇ ${ }^{1}$ Semra ÇIÇO TAMNIK ${ }^{2}$
}

\begin{abstract}
Özet: Araştırma, Kosova’ da Prizren Üniversitesi Eğitim Fakültesi Okul Öncesi Öğretmenliği bölümünde okuyan okul öncesi öğretmen adaylarının çocuk sevgisi ve mesleki kaygı düzeylerinin belirlenmesi amacıyla yapılmıştır. Araştırmanın verileri, 2019-2020 ögretim yılında Prizren Üniversitesi Ĕ̆itim Fakültesi Okul Öncesi Öğretmenliği bölümünde öğrenim gören 80 ögrenciye "Barnett Çocuk Sevme Ölçeğì" ve "Öğretmen Adayı Kaygı Ölçeği” nin uygulanmasıyla elde edilmiştir. Araştırma sonucunda okul öncesi öğretmen adaylarının çocuk sevgisi düzeylerinin yüksek, mesleki kaygı düzeylerinin ise düşük olduğu tespit edilmiştir.
\end{abstract}

Anahtar Kelimeler: Çocuk Sevgisi, Meslek Kaygi.

To cite this article: Kovaç, E. S. \&Tamnik, S.Ç. (2021). Okul Öncesi Öğretmen Adaylarının Çocuk Sevgisi ve Mesleki Kaygılarının İncelenmesi. Kosovo Educational Research Journal, 2(2), 43-53

\section{GİRIŞ}

Okul çocukların yaşamları için önemli bir kurumdur, yetişmelerinde aile ortamı kadar okul ortamı da önemli bir yerdir. Aile içerisinde anne baba, okulda ise öğretmen çocukların eğitimini sağlamaktadır. Bu nedenle öğretmenlerin bir takım becerilere sahip bireyler olması gerekmektedir.

Öğretmenler bir çok niteliğe sahip olmalılardır, öğretmenliğin diğer meslekleri ortaya çıkaran ana meslek olduğu düşünüldüğünde iyi bir öğretmen olmanın mesleki bilgiler dışında da birçok özelliğe sahip olması gekmektedir. Öğretmenlerin insanları seven, fedakarlık gösterebilern, hoş görülü ve sabırlı olmaları gerekmektedir (Helvacı, 2009). Öğrenme sürecinde

\footnotetext{
${ }^{1}$ Prizren Ukshin Hoti Üniversitesi, Eğitim Fakültesi Öğretim Görevlisi

${ }^{2}$ Prizren Ukshin Hoti Üniversitesi, Eğitim Fakültesi Öğrencisi.
} 
bireysel farklılıkların olması öğretmenlerin de öğrencilere karşı gösterecekleri tutum ve çabalarının öğrencileri sevmeden gerçekleşmesi mümkün değildir (Özkal, 2020). Okul öncesi öğretmenlerin, ilk çocukluk dönemindeki çocuklara verdikleri eğitim dönemi kritik bir dönem olduğu için eğitim ortamının ve eğitim verimliliğinin olumlu yansıması için çocuk sevme önemli bir öğretmen yeterliliği olarak karşımıza çıkmaktadır (Kaynak, Ergin, Arslan, Pınarcık, 2015). Öğretmenler bilgiyi veya davranışları çocuklara kazandırmak için öğrencilere sevgi ile yaklaşmalıdırlar (Gelbal ve Duyan, 2010).

Öğretmenin çocuklara yaklaşımı ve tutumu, işini yaparken mutlu olması, etkinliklerde çocuklarla birlikte çalışması, çocukların ihtiyaçlarını belirleyebilmesi, çocuklara konularda destekleyici ve rehberlik etmesi olumlu öğretmen-öğrenci ilişkisinin en önemli unsurlarındandır (Bin Dahari ve Sabri bin Ya, 2011). Öğretmenlerin mesleki sorumluluklarının yanı sıra meslek sevgisinin de mesleki yeterlilik kadar önemi büyüktür. Mesleki sorumluluklar yerine getirilirken öğretmenler kaygı yaşayabilirler (Hockenberry ve Wilson 2011; Çavuşoğlu, 2013).

Çocuklarla yoğun iletişim ve konsantrasyon, dikkat edilmeyi gerektiren bir meslek olan okul öncesi eğitiminde çalışan öğretmenlerde çeşitli sorunlarla karşılaşabilir. Okul öncesi öğretmenlerinin, işlerinin gereği ile öğrencilerinin aileleri ile iletişimlerinin fazla olması, sınıftaki çocukların bedensel, zihinsel, sosyal gelişimleri ile ve eğitimleri ile sürekli yakından ilgileniyor olmaları, sınıflarında aralıksız eğitim sürdürmeleri ve sınıflarındaki fazla öğrenci sayısı olması gibi nedenlerle okul öncesi öğretmenleri kaygı durumu yaşayabilir (Gümrükçü Bilgici ve Deniz, 2016).

Öğretmen adaylarının mesleğe yönelik kaygılarının neler olduğunu bilmek ve bu konuda çalışmalarda bulunmak eğitim kalitesini ve nitelikli öğretmen yetiştirme konusunda oldukça önemlidir. Üniversite yılları, öğrencinin önemli yılları olmakla birlikte kaygılarının oldukça fazla olduğu dönemlerdi. Bir öğrenci için okul yılları onun yaşamının en önemli yıllarını kapsar. Üniversite öğrencilerinin artık ilköğretim ve lise dönemi geride kalmış ve öğrenciliklerinin son anlarının yaklaşıldığı bu dönemlerde mezun olduktan sonra ne olacak sorusu kaygılarının artmasına neden olacaktır. Bu yıllarda öğrencilerin kaygı durumlarının arttığı tespit edilmiştir (Çakmak ve Hevedanlı, 2005; Bozkurt, 2004). Bu kaygıların çoğu kişilerin mezun olduktan sonra iş ve işsizlik konularında ortaya çıkmaktadır. Öğrenciler, mezun olduktan sonra geçimlerini nasıl sürdürecekleri, iş bulup bulamayacakları ya da istedikleri işte çalışıp çalışamayacakları sorularını sıkça dile getirebilmektedirler (Bozdam, 2008). Yapılan 
çalışmalara bakıldığında çocuk sevgisi ve mesleki kaygı değişkenleri ile yapılan birçok çalışmaya rastlanmıştır, ancak Kosova'da çocuk sevgisi ve mesleki kaygı değişkenleri ile yapılan herhangi bir çalışma bulunmamaktadır. Bu noktadan hareketle bu araştırmada, Kosova' da Prizren Üniversitesi Eğitim Fakültesi Okul Öncesi Öğretmenliği bölümünde okuyan okul öncesi öğretmen adaylarının çocuk sevgisi ve mesleki kaygı düzeylerinin belirlenmesi amaçlanmıştır. Bu amaç doğrultusunda aşağıdaki sorulara cevap aranmıştır:

1. Okul öncesi öğretmen adaylarının çocuk sevgisi düzeyleri nasıldır?

2. Okul öncesi öğretmen adaylarının mesleki kaygı düzeyleri nasıldır ?

\section{YÖNTEM}

\section{Araştırmanın Modeli}

$\mathrm{Bu}$ araştırma; okul öncesi öğretmen adaylarının mesleki kaygı düzeyleri ve çocuk sevgisi düzeylerine ilişkin görüşleri alınarak, bu görüşlerin betimlendiği nicel bir çalışmadır. Bu çalışma, var olan bir durumun, var olduğu hali ile betimlenmesine yönelik betimsel bir araştırmadır (Büyüköztürk, 2011).

\section{Araştırma Grubu}

Araştırma grubunu, 2019-2020 öğretim yılında Prizren Üniversitesinde Türkçe Okul Öncesi Öğretmenliği bölümünde öğrenim gören (1. Sınıftan 4. Sınıfa kadar) öğrenciler oluşturmaktadır.

Tablo 1. Katılımcıların Cinsiyetlerine Göre Dağılımı

\begin{tabular}{|c|c|c|}
\hline Cinsiyet & Frekans & Yüzdelik \\
\hline Kadın & 72 & 90 \\
\hline Erkek & 8 & 10 \\
\hline Toplam & 80 & 100 \\
\hline
\end{tabular}

\section{Veri Toplama Araçları}

Veri toplama aracı olarak "Öğretmen Adayı Kaygı Ölçeği” ve "Barnet Çocuk Sevme Ölçeği” kullanılmıştır.

\section{Öğretmen Adayı Kaygı Ölçeği}


Okul öncesi öğretmen adaylarının gelecek kaygı düzeylerini belirlemek amacıyla Saban, Korkmaz ve Akbaşlı (2004) tarafından Borich’ten (1996) uyarlanarak geliştirilen “Öğretmen Adayı Kaygı Ölçeği” kullanılmıştır. “Öğretmen Adayı Kaygı Ölçeği” 45 maddelik 5'li likert tipinde bir ölçektir.“Çok kaygılanıyorum”, “Oldukça kaygılanıyorum”,"Kısmen kaygılanıyorum”, “Çok az kaygılanıyorum” ve "Kaygılanmıyorum” şeklinde derecelendirilmiştir. Öğretmen Adayı Kaygı Ölçeği üç faktörden oluşmaktadır. Ölçeğin birinci boyutu "Ben Merkezli Kaygılar" 15 madde, ikinci boyutu "Görev Merkezli Kaygılar" 15 madde ve üçüncü boyutu “Öğrenci Merkezli Kaygılar” 15 madde içermektedir.

\section{Barnet Çocuk Sevme Ölçeği}

Barnett Çocuk Sevme Ölçeği: Barnett ve Sinisi, (1990) tarafından insanların çocuklara yönelik tutumlarını ölçme amacıyla geliştirilmiş ve Türkiye için güvenirlik ve geçerlik çalışması Duyan ve Gelbal (2008) tarafından yapılmış olan bir değerlendirme aracıdır. Ölçekte bireylerin çocukları sevme durumunu belirlemeye yönelik on dört madde bulunmaktadır. Maddelerde belirtilen düşünceye, bireylerden "Hiç katılmıyorum" yanıtından, "Tamamen katılıyorum" yanıtına kadar değişkenlik gösteren yedi derecede görüş bildirmeleri istenmektedir. Çocukları sevmeyi belirlemeye yönelik maddelerden dördü olumsuz (3, 6, 10 ve 13. maddeler) ve onu da olumlu anlam taşımaktadır.

\section{Verilerin Toplanması}

Veri toplama araçları Prizren Üniversitesi Türkçe Okul Öncesi Öğretmenliği Bölümünde okuyan 1. den 4. sınıfa kadar tüm gönüllü öğrencilere uygulanmıştır. Toplamda 82 kişiye uygulanan anketler arasında 2 ölçek eksik doldurulduğu için veri setinden çıkarılmıştır, dolayısıyla veri setinde 80 ölçek işleme ve değerlendirmeye alınmıştır. Veriler 2019-2020 öğretim yılının Bahar döneminde toplanmış ve analiz edilmiştir.

\section{Verilerin Analizi}

Öğretmen adaylarına uygulanan ölçeklerden elde edilen veriler kodlanarak bilgisayar ortamına girilmiştir. Elde edilen verilerin çözümlenmesinde SPSS 16.0 for Windows Evaluation Version istatistik paket programı kullanılmıştır. Toplanan veriler SPSS paket programı yardımı ile istatistiki işlemlere tabi tutulmuş ve elde edilen sonuçlar tablo haline getirilmiştir. 
Verilerin çözümlenmesinde; betimsel istatistik tekniklerinden, frekans (f) ve yüzdelik (\%) hesaplamaları yapılmıştır. Betimsel istatistik, bir değişkene ilişkin sayısal değerlerin toplanması, betimlenmesi ve sunulmasına olanak sağlayan istatistiksel işlemleri tanımlar (Büyüköztür, 2011).

\section{BULGULAR}

Araştırmanın bulguları, araştırma sorularına göre; okul öncesi öğretmen adaylarının çocuk sevgisi düzeyleri ve mesleki kaygı düzeyleri olmak üzere iki bölümde incelenmiştir.

Tablo 2. Okul Öncesi Öğretmen Adaylarının Çocuk Sevgisi Düzeyleri

\begin{tabular}{|c|c|c|c|c|c|c|c|}
\hline \multicolumn{4}{|c|}{ Frekans } & \multicolumn{3}{|l|}{ Yüzdelik } & \multirow[t]{2}{*}{ Total } \\
\hline & $\begin{array}{l}\text { Hiç } \\
\text { katılmıyoru } \\
\text { m }\end{array}$ & $\begin{array}{l}\mathrm{Ne} \\
\text { katıliyorum } \\
\text { ne } \\
\text { katılmıyoru } \\
\text { m }\end{array}$ & $\begin{array}{l}\text { Tamamen } \\
\text { katıliyoru } \\
\mathrm{m}\end{array}$ & $\begin{array}{l}\text { Hiç } \\
\text { katılmıyorum }\end{array}$ & $\begin{array}{l}\mathrm{Ne} \\
\text { kat1liyoru } \\
\text { m ne } \\
\text { katılmiyor } \\
\text { um }\end{array}$ & $\begin{array}{l}\text { Tamamen } \\
\text { katıliyoru } \\
\mathrm{m}\end{array}$ & \\
\hline $1 \mathrm{M}$ & 6 & 2 & 72 & 7,5 & 2,5 & 90 & $\begin{array}{l}\text { 80/10 } \\
0 \\
\end{array}$ \\
\hline $2 M$ & 1 & 4 & 75 & 1,3 & 5,0 & 93,8 & $\begin{array}{l}80 / 10 \\
0\end{array}$ \\
\hline $3 M$ & 58 & 9 & 13 & 72,5 & 11,3 & 16,3 & $\begin{array}{l}80 / 10 \\
0\end{array}$ \\
\hline $4 M$ & 1 & 2 & 77 & 1,3 & 2,5 & 96,3 & $\begin{array}{l}80 / 10 \\
0\end{array}$ \\
\hline $5 \mathrm{M}$ & I & 1 & 79 & I & 1,3 & 98,8 & $\begin{array}{l}80 / 10 \\
0 \\
\end{array}$ \\
\hline $6 \mathrm{M}$ & 70 & 2 & 8 & 87,5 & 2,5 & 10,0 & $\begin{array}{l}80 / 10 \\
0\end{array}$ \\
\hline $7 \mathrm{M}$ & I & 9 & 71 & I & 11,3 & 88,8 & $\begin{array}{l}80 / 10 \\
0 \\
\end{array}$ \\
\hline $8 \mathrm{M}$ & I & 6 & 74 & I & 7,5 & 92,5 & $\begin{array}{l}80 / 10 \\
0\end{array}$ \\
\hline 9M & 5 & 10 & 65 & 6,3 & 12,5 & 81,3 & $\begin{array}{l}80 / 10 \\
0 \\
\end{array}$ \\
\hline $\begin{array}{l}10 \\
M\end{array}$ & 73 & 4 & 3 & 91,3 & 5,0 & 3,8 & $\begin{array}{l}80 / 10 \\
0\end{array}$ \\
\hline $\begin{array}{l}11 \\
M\end{array}$ & 1 & 1 & 78 & 1,3 & 1,3 & 97,5 & $\begin{array}{l}80 / 10 \\
0 \\
\end{array}$ \\
\hline $\begin{array}{l}12 \\
M\end{array}$ & 1 & 7 & 72 & 1,3 & 8,8 & 90,0 & $\begin{array}{l}80 / 10 \\
0\end{array}$ \\
\hline $\begin{array}{l}13 \\
\text { M }\end{array}$ & 51 & 21 & 8 & 63,8 & 26,3 & 10,0 & $\begin{array}{l}80 / 10 \\
0\end{array}$ \\
\hline
\end{tabular}




\begin{tabular}{|l|l|l|l|l|l|l|l|}
\hline $\mathbf{1 4}$ & $/$ & $/$ & $\mathbf{8 0}$ & $/$ & $/$ & $\mathbf{8 0}$ & $\begin{array}{l}\mathbf{8 0} / \mathbf{1 0} \\
\mathbf{0}\end{array}$ \\
\hline
\end{tabular}

Tablo 2' de okul öncesi öğretmen adaylarının çocuk sevgisi düzeylerine göre frekans ve yüzde değerleri görülmektedir. Tablo 2'ye bakıldığında, katılımcıların \%90,0'1nın çocukları oyun oynarken izlemekten keyif aldıkları, \%93,8'inin çocukları tanımaktan mutluluk duydukları, \%72,5'inin çocuklarla konuşmaktan hoşlandıkları sonucuna ulaşılmıştır. Katılımcıların \%96,3'ünün çocukları kucaklamaktan mutluluk duydukları, \%98,8'ının çocuklkarın gülümsediği zaman mutlu oldukları, \%87,5'inin etraflarında çocukların bulunmasından mutluluk duyduğu, \%88,8'inin çocukları parkta oynarken izlemekten keyif aldıkları, \%92,5'inin çocuklarla birlikte zamanın nasıl geçtiğini fark etmedikleri, \%81,3'ünün çocukların aralarındaki konuşmaları dinlemekten keyif aldıkları sonucuna ulaşılmıştır. Katılımcıların \%91,3'ünün çocukları rahatsız edici bulmadıkları, \%97,5'inin çocukların gülümsemesi için çaba harcamaktan keyif aldıkları, \%90,0'ının bütün çocukları sevimli buldukları, \%63,8'inin çocukların bağrışması ve etrafta koşturmalarının rahatsız edici olmadığını ve \%100,0'ünün çocukları sevdiklerine ilişkin tamamen katıldıkları yönünde görüş belirttikleri görülmektedir.

Tablo 3. Okul Öncesi Öğretmen Adaylarının Mesleki Kaygı Düzeyleri

\begin{tabular}{|c|c|c|c|c|c|c|c|c|c|c|c|}
\hline \multicolumn{6}{|c|}{ Frekans } & \multicolumn{5}{|c|}{ Yüzdelik } & \multirow[t]{2}{*}{ Total } \\
\hline & $\frac{\vec{\Xi}}{\vec{\sigma}_{0}}$ & 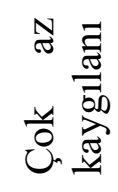 & 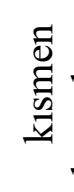 & 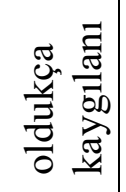 & 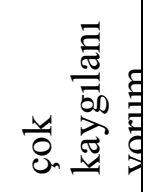 & 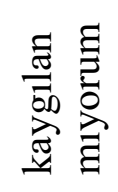 & 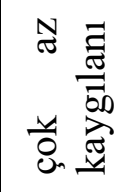 & 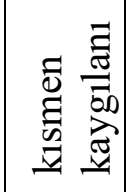 & 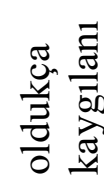 & 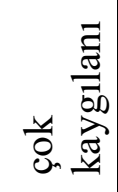 & \\
\hline $1 \mathrm{M}$ & 21 & 11 & 20 & 19 & 9 & 26,3 & 13,8 & 25,0 & 23,8 & 11,3 & $80 / 100$ \\
\hline $2 M$ & 36 & 23 & 8 & 6 & 7 & 45,0 & 28,8 & 10,0 & 7,5 & 8,8 & $80 / 100$ \\
\hline $3 M$ & 30 & 16 & 20 & 10 & 4 & 37,5 & 20,0 & 25,0 & 12,5 & 5,0 & $80 / 100$ \\
\hline $4 M$ & 22 & 24 & 18 & 12 & 4 & 27,5 & 30,0 & 22,5 & 15,0 & 5,0 & $80 / 100$ \\
\hline $5 M$ & 30 & 23 & 13 & 11 & 3 & 37,5 & 28,8 & 16,3 & 13,8 & 3,8 & $80 / 100$ \\
\hline 6M & 28 & 21 & 21 & 4 & 6 & 35,0 & 26,3 & 26,3 & 5,0 & 7,5 & $80 / 100$ \\
\hline $7 \mathrm{M}$ & 22 & 30 & 16 & 8 & 4 & 27,5 & 37,5 & 20,0 & 10,0 & 5,0 & $80 / 100$ \\
\hline $8 M$ & 30 & 20 & 19 & 8 & 3 & 37,5 & 25,0 & 23,8 & 10,0 & 3,8 & $80 / 100$ \\
\hline 9M & 42 & 19 & 9 & 6 & 4 & 52,5 & 23,8 & 11,3 & 7,5 & 5,0 & $80 / 100$ \\
\hline $10 M$ & 22 & 33 & 12 & 12 & 1 & 27,5 & 41,3 & 15,0 & 15,0 & 1,3 & $80 / 100$ \\
\hline $11 M$ & 16 & 28 & 23 & 7 & 6 & 20,0 & 35,0 & 28,8 & 8,8 & 7,5 & $80 / 100$ \\
\hline $12 M$ & 25 & 28 & 18 & 7 & 2 & 31,3 & 35,0 & 22,5 & 8,8 & 2,5 & $80 / 100$ \\
\hline $13 M$ & 35 & 18 & 11 & 10 & 6 & 43,8 & 22,5 & 13,8 & 12,5 & 7,5 & $80 / 100$ \\
\hline $14 M$ & 38 & 22 & 13 & 4 & 3 & 47,5 & 27,5 & 16,3 & 5,0 & 3,8 & $80 / 100$ \\
\hline $15 M$ & 31 & 22 & 15 & 9 & 3 & 38,8 & 27,5 & 18,8 & 11,3 & 3,8 & $80 / 100$ \\
\hline $16 M$ & 19 & 23 & 25 & 8 & 5 & 23,8 & 28,8 & 31,3 & 10,0 & 6,3 & $80 / 100$ \\
\hline 17M & 22 & 24 & 18 & 12 & 4 & 27,5 & 30,0 & 22,5 & 15,0 & 5,0 & $80 / 100$ \\
\hline
\end{tabular}




\begin{tabular}{|c|c|c|c|c|c|c|c|c|c|c|c|}
\hline $18 M$ & 31 & 23 & 12 & 11 & 3 & 38,8 & 28,8 & 15,0 & 13,8 & 3,8 & $80 / 100$ \\
\hline 19M & 25 & 28 & 9 & 8 & 10 & 31,3 & 35,0 & 11,3 & 10,0 & 12,5 & $80 / 100$ \\
\hline $20 M$ & 26 & 31 & 10 & 9 & 4 & 32,5 & 38,8 & 12,5 & 11,3 & $\mathbf{3 , 8}$ & $80 / 100$ \\
\hline $21 M$ & 25 & 26 & 17 & 9 & 3 & 31,3 & 32,5 & 21,3 & 11,3 & 3,8 & $80 / 100$ \\
\hline $22 M$ & 31 & 26 & 14 & 7 & 2 & 38,8 & 32,5 & 17,5 & 8,8 & 2,5 & $80 / 100$ \\
\hline $23 M$ & 42 & 15 & 8 & 12 & 3 & 52,5 & 18,8 & 10,0 & 15,0 & 3,8 & $80 / 100$ \\
\hline $24 M$ & 46 & 12 & 9 & 6 & 7 & 57,5 & 15,0 & 11,3 & 7,5 & 8,8 & $80 / 100$ \\
\hline $25 M$ & 13 & 16 & 21 & 18 & 12 & 16,3 & 20,0 & 26,3 & 22,5 & 15,0 & $80 / 100$ \\
\hline $26 M$ & 31 & 21 & 14 & 11 & 3 & 38,8 & 26,3 & 17,5 & 13,8 & 3,8 & $80 / 100$ \\
\hline 27M & 36 & 22 & 14 & 4 & 4 & 45,0 & 27,5 & 17,5 & 5,0 & 5,0 & $80 / 100$ \\
\hline 28M & 33 & 25 & 9 & 10 & 3 & 41,3 & $\mathbf{3 1 , 3}$ & 11,3 & 12,5 & $\mathbf{3 , 8}$ & $80 / 100$ \\
\hline 29M & 22 & 29 & 14 & 11 & 4 & 27,5 & 36,3 & 17,5 & 13,8 & 5,0 & $80 / 100$ \\
\hline 30M & 21 & 23 & 14 & 11 & 11 & 26,3 & 28,8 & 17,5 & 13,8 & 13,8 & $80 / 100$ \\
\hline $31 \mathrm{M}$ & 22 & 16 & 14 & 16 & 2 & 27,5 & 32,5 & 17,5 & 20,0 & 2,5 & $80 / 100$ \\
\hline $32 M$ & 44 & 14 & 8 & 10 & 4 & 55,0 & 17,5 & 10,0 & 12,5 & 5,0 & $80 / 100$ \\
\hline 33M & 26 & 31 & 8 & 12 & 3 & 32,5 & 38,8 & 10,0 & 15,0 & $\mathbf{3 , 8}$ & $80 / 100$ \\
\hline $34 \mathrm{M}$ & 26 & 31 & 10 & 11 & 2 & 32,5 & 38,8 & 12,5 & 13,8 & 2,5 & $80 / 100$ \\
\hline $35 M$ & 28 & 24 & 13 & 6 & 9 & 35,0 & 30,0 & 16,3 & 7,5 & 11,3 & $80 / 100$ \\
\hline $36 M$ & 28 & 27 & 14 & 6 & 5 & 35 & $\mathbf{3 3 , 8}$ & 17,5 & 7,5 & 6,3 & $80 / 100$ \\
\hline 37M & 33 & 16 & 19 & 9 & 3 & 41,3 & 20,0 & 23,8 & 11,3 & $\mathbf{3 , 8}$ & $80 / 100$ \\
\hline $38 M$ & 30 & 22 & 14 & 7 & 7 & 37,5 & 27,5 & 17,5 & 8,8 & 8,8 & $80 / 100$ \\
\hline 39M & 33 & 28 & 9 & 7 & 3 & 41,3 & 35,0 & 11,3 & 8,8 & 3,8 & $80 / 100$ \\
\hline 40M & 27 & 25 & 14 & 8 & 6 & 33,8 & 31,3 & 17,5 & 10,0 & 7,5 & $80 / 100$ \\
\hline
\end{tabular}

Tablo 3' te okul öncesi öğretmen adaylarının mesleki kaygı düzeylerine göre frekans ve yüzde değerleri görülmektedir. Tablo 3'e bakıldığında katılımcıların \%26,3' ünün okul yönetiminde yeterli yardım almaya ilişkin kaygı yaşamadıkları, \%11,3'ünün ise çok kaygı yaşadıkları sonucuna ulaşılmıştır. Katılımcıların \%45,0'inin sınıfındaki öğrencilerinin saygısını kazanabilmeye ilişkin kaygı yaşamadıkları, \%37,5'inin öğretimle ilgili sorumluluklarla baş edebilmeye ilişkin kaygı yaşamadıkları, \%30'unun sınıfında yöneticiler tarafından gözleniyorken başarılı olabileceklerine ilişkin çok az kaygı yaşadıkları sonucuna ulaşılmıştır. Katılımcıların \%37,5 , inin öğrencilerin öğrenmelerine yönelik olumlu bir tutum geliştirebileceklerine ilişkin kaygı yaşamadıkları, \%35,0'inin hem öğretime hazırlık yapabilmek hem de dinlenmek için yeterli zaman bulabileceklerine ilişkin kaygı yaşamadıkları, \%37,5'inin okuldaki branş öğretmenlerinden veya diğer uzmanlardan yardım alabilmeye ilişkin çok az kaygı yaşadıkları sonucuna ulaşılmıştır. Araştırmaya katılanların \%37,5'inin sınıfında öğretim için sahip olduğu zamanı etkin olarak kullanabilmeye ilişkin kaygı yaşamadıkları, \%52,5'inin okuldaki meslektaşlarının kendilerine olan saygılarını kazanabilmelerine ilişkin kaygı yaşamadıkları, \%41,3'ünün öğrencileri objektif olarak değerlendirebilmek için yeterli zaman bulabilmeye ilişkin çok az kaygı yaşadıkları, \%35,0'inin öğretim programının değişmezliği ile başa çıkabilmeye ilişkin çok az kaygı yaşadıkları, 35,0’inin öğretmenlerden 
beklenen standartları karşılayabilmeye ilişkin çok az kaygı yaşadıklarısonucuna ulaşılmıştır. Katılmcıların \%43,8'inin kaliteli planları hazırlamak için yeterli bilgi ve beceriye sahip olmaya ilişkin kaygı yaşamadıkları, \%47,5'inin okuldaki diğer öğretmenler yetersiz olduğu alanların farkına varabilmeye ilişkin kaygı yaşamadıkları, \%38,8'inin öğrencilerinde kendilerine güven ve başarı duygularını geliştirmeye ilişkin kaygı yaşamadıkları, \%28,8’inin okuldaki öğretim programının dışına çıkabilmeye ilişkin çok az kaygı yaşadıkları, \%30,0'unun sınıfında öğrenme güçlügü çeken öğrencilerinin problemlerini teşhis edebilmeye ilişkin çok az kayg1 yaşadıkları sonucuna ulaşılmıştır. Araştırmaya katılanların \%38,8'inin sınıfında çok gürültü olduğunda okul müdürünün olumsuz düşüncesine maruz kalmaya ilişkin kaygı yaşamadıkları, \%35,0’inin sınıfındaki her öğrenciye kendi potansiyelinin keşfetmesi ve geliştirebilmesine yardım edebilmeye ilişkin çok az kaygı yaşadıkları, \%32,5'inin öğretmenliği hakkında yapılan teftişlerde olumlu değerlendirmeler elde edebilmeye ilişkin kaygı yaşamadıkları, \%32,5'inin sınıfı çok kalabalık olursa öğrencilerle baş edebilmeye ilişkin kaygı yaşamadıkları sonucuna ulaşılmışır. Katılımcıların \%38,8'inin sınıfındaki öğrencilerinin sosyal ve duygusal ihtiyaçlarının farkına varabilmeye ilişkin kaygı yaşamadıkları, \%52,5'inin sınıfındaki motivasyonu düşük olan öğrencilerini öğrenmeye cesaretlendirip, onların çabalarını destekleyebilmeye ilişkin kaygı yaşamadıkları, \%57,5'inin sınıfındaki öğrencilerinin sevgisini kazanmaya ilişkin kaygı yaşamadıkları, \%22,5'inin sınıfında tasarladı̆̆ı farklı etkinlikleri gerçekleştirebilmek için gerekli olan harcamalar konusunda, okul yönetiminden maddi destek alabilmeye ilişkin oldukça kaygı yaşadıkları sonucuna ulaşılmıştır. Aeaştırmaya katılan okul öncesi öğretmen adaylarının \%38,8'inin etkin bir sınıf yönetimi için yeterli bilgi ve beceriye sahip olabilmeye ilişkin kaygı yaşamadıkları, \%45,0'inin etkili ve verimli ders planları hazırlamak için gerekli olan zamanı bulabilmeye ilişkin kaygı yaşamadıkları, \%41,3'ünün öğrencilerinin sınıftaki kurallar doğrultusunda davranmalarını sağlayabilmeye ilişkin kaygı yaşamadıkları sonucuna ulaşılmıştır. Katılımcıların \%36,3'ünün sınıfındaki bazı öğrencilerin neden yavaş öğrendiklerini anlayabilmeye ilişkin çok az kaygı yaşadıkları, \%28,8'inin sınıfında sorumlu tutulacağı utanç verici bir olayla karşı karşıya kalmaya ilişkin çok az kaygı yaşadıkları, \%32,5'inin sınıfında sürekli sorun çıkaran öğrencilerle başa çıkabilmeye ilişkin çok az kaygı yaşadıkları sonucuna ulaşılmıştır. Katılımcıların \%55,0'inin okuldaki meslektaşları onun öğretmenliği bakımından yetersiz olduğu düşüncelerine ilişkin kaygı yaşamadıkları, \%38,8'inin sınıfında huzurunu bozan öğrencilerle birlikte çalışmak için gerekli bilgi, beceri ve anlayışa sahip olabilmeye ilişkin çok az kaygı yaşadıkları, \%32,5'inin öğrencilerinin beslenme ve sağlı problemlerinin öğrenmelerini nasıl etkilediğini anlayabilmeye ilişkin kaygı yaşamadıkları, \%35,0'inin velilerin öğretmenlikleri konusunda yeterli görebilmeye ilişkin 
kaygı yaşamadıkları sonucuna ulaşılmıştır. Araştırmaya katılanların \%35,0'inin sınıfındaki öğrencilerin bireysel ilgi ve ihtiyaçlarını karşılayabilmeye ilişkin kaygı yaşamadıkları, \%41,3’ünün sınıfındaki öğrencilerin konuyu etkili bir şekilde öğrenebilmeleri için alternatif öğretim tekniklerini uygulayabilmeye ilişkin kaygı yaşamadıkları, \%37,5'inin öğrencilerinin davranışlarını etkileyebilecek psikolojik ve kültürel farklılıkları anlayabilmeye ilişkin kaygı yaşamadıkları, \%41,3'inin farklı yollarda öğrenen öğrencilerin ihtiyaçlarına kendini adapte edebilmeye ilişkin kaygı yaşamadıkları, \%33,8'inin sahip olduğu öğretim anlayışı ve sınıfta kullandığı öğretim metotlarıyla ilgili idari engellemelerle karşılaşılırsa onlarla başa çıkabilmeye ilişkin kaygı yaşamadıkları sonucuna ulaşılmıştır. Katılmcıların \%27,5'inin sınıfındaki her öğrencinin zihinsel ve duygusal gelişimine rehberlik edebilmeye ilişkin kaygı yaşamadıkları, \%35,0'inin her gün çok sayıda öğrenciyle uğraşabilmeye ilişkin kaygı yaşamadıkları, \%33,8'inin öğrencilerinin okulda öğrendikleri bilgileri okul dışında da uygulamaya koymalarını sağlayabilmeye ilişkin kaygı yaşamadıkları, \%45,0'inin sınıfındaki herhangi bir meslektaşı tarafından gözleniyorken etkili ders işleyebilmeye ilişkin kaygı yaşamadıkları, \%51,3’ünün öğrencilerini öğrenmeye motive edebilmeye ilişkin kaygı yaşamadıkları sonucuna ulaşılmıştır.

\section{Tartışma ve Sonuç}

Araştırma sonucunda okul öncesi öğretmen adaylarının çocuk sevgisi düzeyleri incelendiğinde, çocukları tanımaktan mutluluk duydukları ve onlarla konuşmaktan hoşlandıkları, bir çocuğu gülümsettikleri zaman mutlu oldukları, çocuklarla birlikteyken zamanın nasıl geçtiğini farketmedikleri, çocukların birbiri ile konuşmalarını dinlemekten hoşlandıkları, onları gülümsetmek için çaba harcamaktan keyif aldıkları ve çocukları sevdikleri sonucuna ulaşılmıştır. Alanyazında öğretmen adayları ile yapılan çalışmalara bakıldığında benzer sonuçlara ulaşan bir çok çalışma bulunmaktadır (Özkal, 2019; Konan ve Y1lmaz, 2018; Gelbal ve Duyan, 2010). Öğretmen adaylarının çocuk sevgisi düzeylerinin yüksek olması meslek yaşamlarında öğrencileri ile kuracakları ilişkileri ve eğitim süreçlerini olumlu yönde etkileyeceği düşülmektedir.

Okul öncesi öğretmen adaylarının mesleki kaygı düzeyleri incelendiğinde öğretmen adaylarının okul yönetiminden yardım almaya ilişkin ve yönetim tarafindan incelemeye alındıklarında kaygı yaşamadıklarına ilişkin sonuçlar elde edilmiştir. Okul öncesi öğretmen adaylarının meslektaşlarının kendilerine olan saygılarını kazanabilmeye ilişkin ve okuldaki branş öğretmenlerinden veya diğer uzmanlardan yardım alabilmeye ilişkin kaygı yaşamadıkları sonucu elde edilmiştir. Okul öncesi öğretmen adaylarının öğrencilerini öğrenmeye motive 
edebilme konusunda, kendi öğrencilerine yönelik güven ve başarı duygularına ilişkin, öğrenme güçlügü çeken öğrencilerinin problemlerini teşhiş edebilmeye ve öğrencilerin sosyal duygusal ihtiyaçlarının farkına varabilme konusunda kaygı yaşamadıkları sonucu elde edilmiştir. Okul öncesi öğretmen adaylarının öğrencilerini öğrenmeye cesaretlendirme ve öğrencilerin sevgisini kazanmaya ilişkin kaygı yaşamadıkları sonucu elde edilmiştir.

Okul öncesi öğretmen adaylarının kalabalık bir sınıf ortamında kısmen kaygı yaşayabilecekleri sonucuna ulaşılırken, mesleki yaşamlarında müdürün olumsuz düşüncelerine maruz kalmaya ilişkin ise kaygı yaşadıkları sonucu elde edilmiştir.

Sonuçlara bakıldığında öğretmen adaylarının genel olarak kaygı düzeylerinin düşük düzeyde olduğu ve mesleklerini icra etmek yönünde kaygı yaşamadıkları belirlenmiştir. Öğretmen adaylarının mesleki kaygı düzeylerinin belirlenmesine yönelik yapılan diğer çalışmalarda da benzer sonuçlara ulaşıldığı görülmektedir (Çubukçu ve Dönmez, 2011; Kalemoğlu Varol, Erbaş ve Ünlü, 2014). Bu sonuçlar öğretmen adaylarının daha motive ve kendilerine güvenli bir şekilde mesleklerini icra etmeye yönelik beklentilerinin olduğunu ve bunları öğrencilere ve eğitim ortamına da yansıtacaklarını düşündürmektedir.

\section{Kaynakça}

Bozdam, A.(2008). Öğretmen Adaylarinin Mesleki Kaygi Düzeylerinin Bazi Değişkenler Açisindan Incelenmesi. Yüksek Lisans Tezi. Selçuk Üniversitesi Sağlik Bilimleri Enstitüsü. Konya.

Bozkurt, N.(2004). Bir Grup Üniversite Öğrencisinin Depresyon ve Kayg1 Düzeyleri ile Çeşitli Değişkenler Arasındaki İlişkiler. Ĕgitim ve Bilim. (133): 52-59.

Büyüköztürk, Ş.(2011). Sosyal Bilimler İçin Veri Analizi El Kitabı,Pegam Akademi, Ankara.

Çakmak, Ö., \& Hevedanlı, M. (2005). Eğitim ve Fen-Edebiyat Fakülteleri Biyoloji Bölümü Öğrencilerinin Kaygı Düzeylerinin Çeşitli Değişkenler Açısından İncelenmesi. Elektronik Sosyal Bilimler Dergisi. 4 (14), 115 - 127.

Çavuşoğlu, H. (2013). Çocuk Sağlı̆̆ı Hemşireliği. Cilt 1, Genişletilmiş 11. Bask1, Sistem Ofset Basımevi, Ankara.

Duyan, V. \& Gelbal, S.(2008). Barnett Çocuk Sevme Ölçeği’ni Türkçeye Uyarlama Çalışması. Ĕ̈itim ve Bilim. Cilt 33, Say1148. 
Gelbal, S. \& Duyan, V. (2010). İlköğretim Öğretmenlerinin Çocuk Sevme Durumlarına Etki Eden Değişkenlerin İncelenmesi. Hacettepe Üniversitesi Eğitim Fakültesi Dergisi, 38, 127-137.

Gümrükçü Bilgici, B., Deniz, Ü. (2016). Okul Öncesi Öğretmen Adaylarının Mesleki

Kaygılarının Bazı Demografik Özelliklere Göre İncelenmesi. Cumhuriyet International Journal of Education, 5(1), 53-70.

Helvacı, M.A. (2009).Öğretmenlik Mesleğinin Özellikleri, N. Saylan (Ed), Eğitim Bilimine Giriş, Anı Yayıncılık: Ankara.

Hockenberry Mj, Wilson D. (2011) Wong's Nursing Care of Infants and Children. Ninth Edition, America, Elsevier Mosby Company, 10-15.

Kalemoğlu Varol, Y.; Erbaş, M.K.; Ünlü, H. (2014). Beden Eğitimi Öğretmen Adaylarının Mesleki Kaygı Düzeylerinin Öğretmenlik Mesleğine Yönelik Tutumlarının Yordama Gücü. Ankara Üniversitesi Spor Bilimleri Fakültesi, 12 (2), 113-123.

Kaynak, B.K.; Ergin, B.; Arslan, E. \& Pınarcık, Ö. (2015). Okul Öncesi Öğretmeni Adaylarının Benlik Saygıları İle Çocuk Sevmeleri Arasındaki İlişkinin İncelenmesi. İlköğretim Online, 14(1), 86-96.

Konan, N., ve Yılmaz, S. (2018). Öğretmen Adaylarının Çocukları Sevme Düzeylerine İlişkin Algıları. C. Teyyar, K. Uğurlu, S. Beycioğlu, H. Koşar, F. Kahraman ve Ş. Köybaşı (Ed.) 13. Uluslararası Eğitim Yönetimi Kongresi e-kitap, 66-73.

Özkal, N. (2020). Öğretmen Adaylarının Çocuk Sevme Düzeylerinin Öğretme Motivasyonlarını Yordama Gücü. Trakya Üniversitesi Sosyal Bilimler Dergisi. 2 (2) sy. $885-898$.

Saban, A., Korkmaz, İ., \& Akbaşlı, S. (2004). Öğretmen Adaylarının Mesleki Kaygıları. Eurasian Journal of Educational Research, 19 